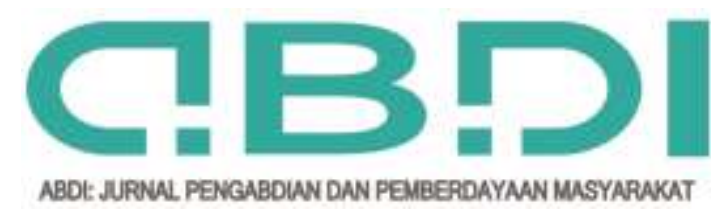

\title{
Pelatihan Desain Pembelajaran Digital Berbasis Living Values Education bagi Guru PPKn SMP di Kabupaten Garut
}

\author{
Kokom Komalasari ${ }^{1}$, Rahmat Rahmat ${ }^{2}$, lim Siti Masyitoh ${ }^{3}$, Dede Iswandi ${ }^{4}$ \\ ${ }^{1,2,3,4}$ Program Studi Pendidikan Kewarganegaraan, Universitas Pendidikan Indonesia \\ E-mail: kokom@upi.edu
}

\begin{abstract}
Abstrak
Kegiatan ini berangkat dari hasil need assessment guru PPKn SMP di Kabupaten Garut yang menunjukkan bahwa sebagain besar guru PPKn mengalami kesulitan dalam mendesain pembelajaran digital untuk mengembangkan sikap kewarganegaraan. Realita ini dikarenakan kurangnya pemahaman teoritis dan praktis guru terhadap desain pembelajaran PKn digital berbasis nilai. Oleh karena itu Universitas Pendidikan Indonesia perlu bersinergi dengan MGMP PPKn SMP Kabupaten Garut untuk melaksanakan Pelatihan Desain Pembelajaran Digital Berbasis Living Values Education bagi Guru PPKn SMP. Tujuan kegiatan pelatihan adalah: 1) Menganalisis bahan pelatihan desain pembelajaran PPKn Digital Berbasis Living Values?; 2) Mendeskripsikan pelaksanaan pelatihan pembelajaran PPKn Digital berbasis Living Values; dan 3) menganalisis peningkatan kemampuan teoritis dan praktis dalam Pembelajaran PPKn Digital Berbasis Living Values? Kegiatan pengabdian menggunakan pendekatan in-on service training dan participant centered training, dengan khalayak sasaran 81 guru PPKn SMP/MTs di Kabupaten Garut. Hasil :1) Bahan pelatihan adalah desain pembelajaran digital PKn yang menerapkan prinsip fun, flexible, and meaningful learning yang mengintegrasikan prinsip living values education melalui Langkah-langkah ice breaker dan opener, purposive cretaive thinking, peer to peer interaction, streaming expert, mental qymnastic, dan reflection; 2) Pelaksanaan kegiatan pelatihan meliputi tahapan persiapan, pelaksanaan model in-on service training, monitoring dan evaluasi pelatihan; 3) Hasil pelatihan menunjukkan bahwa sebagian besar peserta memahami cara mendesain pembelajaran PPKn digital berbasis living values education, tetapi pada aspek penerapannya perlu pendampingan lebih intens dengan menggunakan model lesson study.
\end{abstract}

Kata kunci: Desain pembelajaran digital, Guru, Living Values education, Pelatihan, PPKn

Abstract

This activity departed from the results of the need assessment of Civic Education junior high school teachers in Garut Regency which showed that most of the civics teachers had difficulties in designing digital learning to develop civic attitudes. This reality is due to the teacher's lack of theoretical and practical understanding of the value-based digital Civics learning design. Therefore, Universitas Pendidikan Indonesia needs to synergize with MGMP PPKn SMP in Garut Regency to carry out digital learning design training based on living values education for Civic Education SMP teachers. The objectives of the training activities are: 1) Analyzing the teaching materials for digital Civics learning design based on living values?; 2) Describe the implementation of the digital civics learning training based on living values; and 3) analyze the improvement of theoretical and practical abilities in living values-based digital civics learning? The service activity uses an inon service training approach and participant centered training, with a target audience of 81 Civic Education SMP/MTs teachers in Garut Regency. Results: 1) The training materials include material on Civics digital learning design that applies the principles of fun, flexible, and meaningful learning which integrates the principles of living values education through the steps of ice breaker and opener, purposive creative thinking, peer to peer interaction, streaming expert, mental qymnastic, and reflection; 2) The implementation of training activities includes the stages of preparation, implementation of the in-on service training model, monitoring and evaluation of training; 3) The results of the training show that most of the participants understand how to design digital Civics learning based on living values education, but in the aspect of its implementation, more intense assistance is needed by using the lesson study model.

Keywords: Digital learning design, Teacher, Living Values education, Training, Civics Learning 
Kokom Komalasari, et al.

\section{Pendahuluan}

Kebijakan Pembelajaran Jarak Jauh (PJJ) Kemendikbud berdasarkan Surat Edaran Menteri Pendidikan dan Kebudayaan Nomor 4 Tahun 2020 Tentang Pelaksanaan Kebijakan Pendidikan dalam Masa Darurat Penyebaran Coronavirus Disease (Covid-19) dianggap sebagai satu-satunya kebijakan yang memungkinkan proses pembelajaran PPKn tetap bisa dilakukan di tengah pandemi COVID-19). Dalam prakteknya guru PPKn menghadapi kesulitan beradaptasi dengan metode pembelajaran PJJ. Pada umumnya guru baru pertama kali melakukan pembelajaran dari jarak jauh. Dengan adanya pandemi COVID-19, sekolah mengerti bahwa proses belajar tidak bisa dilakukan dalam waktu yang lama seperti pada situasi normal. Akibatnya, guru terpaksa memadatkan materi pembelajaran, bahkan penanaman dan pengembangan sikap dan keterampialn kurang dikembangkan.

Berdasarkan hasil need assessment terhadap 102 guru PPKn di Kabupaten Garut (Komalasari, et al., 2021) ditemukan bahwa 44,3\% guru PPKn menghadapi kendala dalam kurangnya variasi model pembelajaran PPKn Digital (Pembelajaran Jarak Jauh) di era Pandemi COVID-19, dan 38, $2 \%$ kurangnya pengembangan sikap atau karakter peserta didik dikarenakan kurangnya interaksi secara langsung guru dengan siswa, serta sisanya $17,5 \%$ lemahnya kemampuan melaksanakan penilaian autentik. Berdasarkan data tersebut, maka guru perlu meningkatkan kemampuan dalam: (1) pemahaman konsep dan aplikasi pembelajaran digital; (2) mengembangkan pembelajaran digital yang kreatif dan interaktif; serta (3) pembelajaran digital yang berbasis nilai kehidupan (living values).

Terkait dengan keharusan pembelajaran daring sesuai Surat Edaran Menteri Pendidikan dan Kebudayaan Nomor 4 Tahun 2020 serta hasil need assessment tersebut, maka Guru PPKn sebagai Pendidik pada mata pelajaran kelompok budi pekerti, tentunya berkewajiban secara langsung (direct) mengembangkan sikap/karakter peserta didik. Untuk itu guru memerlukan beberapa kreativitas dan inovasi dalam mendesian variasi pembelajaran daring yang menyenangkan dan menyesuaiakan dengan kebutuhan (fun and flekxible) (Anderson, 2008), dan juga penting mengembangkan pembelajaran berbasis nilai kehidupan (living values). Oleh karena itu, guru PPKn perlu dibekali dengan kemampuan teoritis dan praktis pembelajaran PPKn Digital berbasis Living Values untuk mengembangkan sikap/karakter peserta didik melalui kegiatan pelatihan dengan melibatkan MGMP dan Lembaga Pendidikan Tenaga Kependidikan (LPTK).

Universitas Pendidikan Indonesia sesuai dengan misinya menyelenggarakan pendidikan untuk menyiapkan tenaga pendidik profesional dan tenaga profesional lainnya yang berdaya saing global memiliki peran strategis untuk melaksanakan pengabdian kepada masyarakat dalam bentuk pelatihan profesionalisme guru dengan memanfaatkan bidang ilmu dosen yang relevan. Bidang keilmuan dosen akan lebih bermakna, jika disebarluaskan dan diterapkan kepada guru-guru di persekolahan. Dengan demikian dosen dapat melaksanakan kegiatan Tri Dharma perguruan tinggi komponen pengabdian kepada masyarakat, sehingga bidang kepakaran/keilmuan dosen bermanfaat untuk pengembangan profesionalisme guru-guru di persekolahan yang berdampak pada peningkatan komptensi peserta didik. Ilmu pembelajaran PKn kontekstual, pembelajaran digital, dan living values education yang telah dikembangkan Komalasari dan Saripudin (2017) perlu disebarluaskan melalui kegiatan pengabdian kepada masyarakat sehingga lebih bermanfaat untuk khalayak sasaran, dalam hal ini guru PPKn di persekolahan. Oleh karena itu perlu dilakukan kegiatan Pengabdian kepada Masyarakat berbasis Bidang Imu dalam bentuk kegiatan pelatihan praktis untuk peningkatan kompetensi professional guru (Robinson \& Robinson, 1989; Clark, 1991).

Berdasarkan latar belakang masalah yang teridentifikasi di lapangan dan pentingnya pemanfaatan ilmu pembelajaran PKn digital berbasis hasil living values dalam mengatasi permasalahan tersebut, maka perlu dilakukan Pelatihan Desain Pembelajaran Digital Berbasis Living Values Education bagi Guru PPKn SMP di Kabupaten Garut. Rumusan masalah yang diajukan sebagai berikut:

2. Bagaimana bentuk materi pelatihan desain pembelajaran PPKn Digital Berbasis Living Values bagi guru PPKn SMP Kabupaten Garut?

3. Bagaimana pelaksanaan pelatihan pembelajaran PPKn Digital berbasis Living Values bagi guru PPKn SMP Kabupaten Garut? 
4. Bagaimana peningkatan kemampuan teoritis dan praktis guru PPKn SMP Kabupaten Garut dalam Pembelajaran PPKn Digital Berbasis Living Values setelah mengikuti pelatihan?

\section{Metode Pelaksanaan}

Kegiatan pengabdian kepada masyarakat dilakukan dalam bentuk kegiatan pelatihan (Training) yaitu teknik-teknik yang memusatkan pada belajar tentang ketrampilan-ketrampilan, pengetahuan dan sikap-sikap yang dibutuhkan untuk memulai suatu pekerjaan atau tugas-tugas atau untuk meningkatkan kemampuan dalam melakukan suatu pekerjaan atau tugas (Robinson \& Robinson, 1989; Clark, 1991). Pelatihan guru dilaksanakan berdasarkan prinsip-prinsip belajar pada orang dewasa (adult learning) yaitu pendekatan pelatihan yang berpusat pada peserta (participant centered training) mengacu kepada Pike (2005). Dalam pelatihan dengan Pendekatan participant centered training, para peserta itu sendiri yang seharusnya menjadi pusat perhatian. Artinya, pesertalah yang sesungguhnya mengetahui apa kebutuhan belajar mereka, bagaimana cara belajar yang lebih tepat bagi mereka, untuk bisa memecahkan masalah-masalah yang mereka hadapi.

Desain pelatihan menggunakan desain waktu melalui model in-on service training. Digunakannya model ini didasari pemikiran bahwa desain waktu pelatihan adalah faktor penting dalam menentukan efektifitas sebuah pelatihan. Jika pelatihan hanya dilaksanakan berupa "in service" saja atau 'one-shot' strategy ini kurang efektif dibandingkan dengan 'ongoing programme'. "Ongoing programmes are generally considered more fruitful and effective in achieving the desired objective than one-shot teacher training programs" (Mirici, 2006:157). Sejalan dengan ini, CERI/ Centre for Educational Research and Innovation (1982:54) sependapat bahwa "most in-service training is "ineffective because it is frequently based on one-shot workshops involving a large or in any case undifferentiated group of teachers, and provides limited time for teachers to learn". Dengan kata lain, pelatihan singkat dengan jangka waktu tertentu dianggap kurang efektif karena desain pelatihan seperti ini membatasi kesempatan belajar guru dan mengembangkan pengetahuan dan keterampilan mereka. Model in-on service training ini dilengkapi dengan evaluasi pelatihan dan program tindak lanjut pelatihan. Evaluasi harus dilakukan untuk mengukur tingkat pembelajaran peserta dan perubahan tingkah laku peserta sebagai akibat dari hasil pelatihan (Balchin, et.al., 2006). Program tindak lanjut diberikan agar peserta dapat menerapkan hasil pelatihan dalam praktek langsung di tempat kerja masing-masing tentunya dengan pendampingan dari tutor/fasilitator dan supervise dan monitoring dari pimpinan sekolah.

Metode pelatihan yang digunakan merujuk pada Malcom Knowles (dalam Lieb, 1991) adalah pembelajaran pengalaman (experiential learning) sebagai suatu proses dimana pengalamanpengalaman individu direfleksikan dan dari padanya timbul gagasan atau pengetahuan-pengetahuan baru. Menurut model tersebut, proses pembelajaran bermula dari adanya suatu pengalaman yang diobservasi dan direfleksikan. Dari hasil proses tersebut, individu akan membentuk konsep-konsep abstrak yang kemudian dicobakan pada berbagai situasi baru. Mencoba menerapkan pada situasi baru suatu konsep abstrak yang telah dibentuk, memberikan suatu pengalaman baru lagi bagi individu, demikian seterusnya proses pembelajaran berlangsung, seperti sebuah siklus (Achmat, 2005). Dengan menggunakan model Experiential Learning, maka peran terpenting seorang trainer dalam sebuah pelatihan adalah menjadi fasilitator. Ia berfungsi sebagai perancang pengalaman belajar kreatif. Sebagai fasilitator ia harus menciptakan situasi belajar yang memungkinkan semua peserta memperoleh pengalaman baru atau membantu peserta menata pengalamannya di masa lampau dengan cara baru (Greenway, 2005). Metode pelatihan yang digunakan melibatkan aktifitas-aktifitas yang bersifat participant-centered (berpusat pada peserta) dapat dilakukan melalui role-play, observasi, diskusi, dan brainstorming (Fowlie: 2005), games, case study, simulasi, maupun focused group discussion (Achmat, 2005).

Khalayak peserta pelatihan adalah guru-guru mata pelajaran PPKn pada SMP/MTs di Kabupaten Garut. Jumlah SMP/MTs di Kabupaten Garut sebanyak kurang lebih 200 orang dan yang hadir bergabung dalam zoom cloud meeting sebanyak 81 orang. Peserta berasal dari berbagai SMP/MTs yang tersebar dari 42 Kecamatan di Kabupaten Garut. 


\section{Hasil dan Pembahasan}

\subsection{Bahan Pelatihan: Desain Desain Pembelajaran PKn Digital Berbasis Living Values Education}

Terdapat pergeseran dan perbedaan paradigma pola pembelajaran antara pembelajaran konvensional dengan pembelajaran yang menggunakan teknologi dan antara konsep pembelajaran di kelas (classroom setting) dengan pembelajaran digital yang tidak harus selalu di kelas. Model tersebut memiliki perbedaan dari segi gaya mengajar, teknik serta motivasi pembelajar dan pengajar. Model pembelajaran digital merupakan model masa depan yang efektif karena sesuai dengan tuntutan perkembangan ilmu pengetahuan dan teknologi (Munir,2017). Pembelajaran digital dapat dirumuskan sebagai 'a large collection of computers in networks that are tied together so that many users can share their vast resources'. Dengan kemampuan ini pembelajaran digital dapat diartikan sebagai suatu jaringan komputer yang saling terkoneksi dengan jaringan komputer lainnya ke seluruh penjuru dunia (Anderson, 2008; Munir, 2017).

Pembelajarn digital ini sesuai dengan tuntutan pembelajaram abad 21 dan era revolusi industri 4.0, Oleh karena itu perlu dilakukan strategi pembelajaran digital yang berorientasi pada: 1) Memanfaatkan jasa teknologi elektronik, dengan teknologi elektronik ini guru dan siswa dapat berkomunikasi relatif mudah tanpa dibatasi oleh ruang maupun waktu; 2) Menggunakan bahan ajar bersifat mandiri (self learning materials), sehingga materi pembelajaran tersebut dapat diakses kapan saja dan dimana saja; 3) Jadwal pembelajaran, kurikulum, hasil kemajuan belajar, dan hal-hal yang berkaitan dengan administrasi pendidikan dapat dilihat setiap saat di internet; dan 4) Menggunakan jasa internet sebagai media utama. Internet memberikan sumber belajar dan strategi dalam proses pembelajaran di era digital (Komalasari \& Saripudin, 2017; Komalasari \& Saripudin, 2017a; Komalasari \& Rahmat, 2019; Komalasari et.al., 2021a). Pembelajaran digital dikembangkan dengan prinsip Fun (menyenangkan), Flexible (fleksibel), and Meaningful Learning (Pembelajaran bermakna). Model ini diterapkan melalui Langkah-langkah pembelajaran digital sebagai berikut:

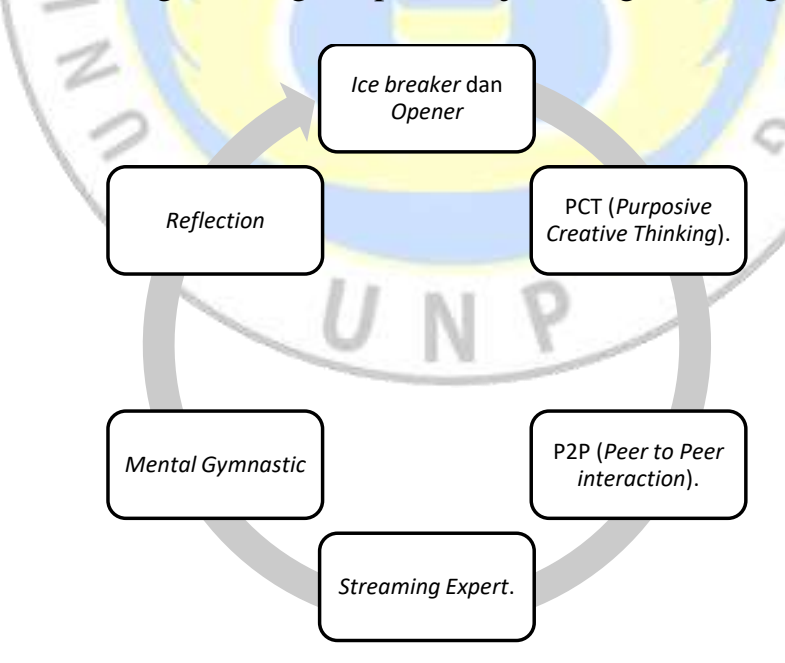

Gambar 1. Langkah-Langkah Pembelajaran Digital

(Komalasari et al., 2021a)

Living Values Education sebagai sebuah prinsip pembelajaran yang menekankan pada prinsip: Refleksi Internal, penerimaan informasi, Eksplorasi Nilai-Nilai dalam Kehidupan Nyata, Dimulai dengan stimulasi nilai sehingga relevansi dan pemaknaannya dapat tercapai, Diskusi, Eksplorasi Ide dan Gagasan, Ekspresi Kreatif, Pengembangan Keterampilan Personal, Sosial, dan Emosional, dan Transfer of Learning-Mengintegrasikan Nilai-Nilai dalam Kehidupan (Komalasari dan Saripudin, 2017; Tillman, 2004). Prinsip Living values education diintegrasikan dalam kegiatan pembelajaran digital secara mikro pada semua tahapan pembelajaran yang meliputi kegiatan pendahuluan, kegiatan inti, dan kegiatan penutup (Komalasari, 2010; Komalasari dan Saripudin, 2017a; Bonk dan Dennen, 
Kokom Komalasari, et al.

2003; Tillman, 2004). Desain Pembelajaran PKn Digital Berbasis Living Values Education disusun sebagai berikut.

\section{Tabel 1. Langkah-Langkah Pembelajaran PKn Digital Berbasis Living Values Education}

\begin{tabular}{|c|c|c|c|}
\hline No & Tahapan & Kegiatan & Deskripsi Langkah-langkah Kegiatan \\
\hline A & $\begin{array}{l}\text { Kegiatan } \\
\text { Pendahuluan }\end{array}$ & \begin{tabular}{l} 
Kontrak Kelas \\
Pendidikan \\
\multicolumn{2}{l}{ Kewarganegaraan } \\
Berkarakter yang \\
menerapkan nilai-nilai \\
kehidupan (living \\
values) yang \\
dilakukan pada awal \\
semester:
\end{tabular} & $\begin{array}{l}\text { 1. Brainstorming siswa mengeksplorasi dan } \\
\text { menyepakati nilai-nilai kehidupan yang akan } \\
\text { dikembangkan bersama di kelas. } \\
\text { 2. Kesepakatan aturan belajar (kontrak belajar) } \\
\text { Pendidikan Kewarganegaraan. }\end{array}$ \\
\hline B & $\begin{array}{l}\text { Kegiatan } \\
\text { Membuka } \\
\text { Pembelajaran }\end{array}$ & $\begin{array}{l}\text { Ice breaker dan } \\
\text { Opener, }\end{array}$ & $\begin{array}{l}\text { 3. Mengkondisikan peserta didik untuk fokus pada } \\
\text { pembelajaran. Guru memberikan treatment untuk } \\
\text { membuat peserta didik termotivasi dan aktif dalam } \\
\text { pembelajaran melalui games, tayangan video } \\
\text { aktivitas \& motivasi, gambar yang relevan dan } \\
\text { menarik untuk focusing pada tujuan pembelajaran. } \\
\text { 4. Apersepsi melalui refleksi internal. Guru mengajak } \\
\text { siswa untuk berpikir dan merenungkan berbagai } \\
\text { pengalaman mereka yang berkaitan dengan nilai-nilai } \\
\text { kehidupan. } \\
\text { 5. Guru menyampaikan tujuan dan rencana kegiatan } \\
\text { pembelajaran }\end{array}$ \\
\hline $\mathrm{C}$ & Kegiatan Inti & & $\begin{array}{l}\text { 6. Mengidentifikasi konflik atau masalah-masalah dalam } \\
\text { kegiatan belajar yang dihadapi oleh peserta didik yang } \\
\text { dapat dipecahkan oleh peserta didik sendiri melalui } \\
\text { fasiltas yang ada, misalnya disscussion forum atau } \\
\text { chatting. } \\
\text { 7. Mengklarifikasi dan menggali nilai-nilai kehidupan } \\
\text { melalui VCT analisis, VCT Daftar, dan VCT games. } \\
\text { 8. Penerimaan Informasi: menggali dan mengeksplorasi } \\
\text { nilai dari literatur/bahan bacaan, cerita dan informasi } \\
\text { tentang budaya yang bersifat positif. } \\
\text { 9. } \begin{array}{l}\text { Eksplorasi nilai-nilai dalam kehidupan nyata dengan } \\
\text { menggunakan games/permainan, analisis situasi } \\
\text { nyata/berita, menyusun drama/role playing, diakhiri }\end{array} \\
\text { dengan eksplorasi nilai-nilai dan bagaimana } \\
\text { penerapnnya pada masing-masing individu. }\end{array}$ \\
\hline & & $\mathrm{P} 2 \mathrm{P}$ (Peer to Peer $)$ & $\begin{array}{l}\text { 10. Penggunaan pendekatan kontekstual melalui strategi: } \\
\text { Project-based learning, Work-based learning, } \\
\text { Problem-based learning, Cooperative Learning, } \\
\text { Service Learning untuk dalam kegiatan peserta didik } \\
\text { di web. Hal ini ada kaitannya dengan kegiatan } \\
\text { sebelumnya yaitu upaya untuk mengatasi masalah- } \\
\text { masalah yang dihadapi oleh peserta didik yang } \\
\text { dicarikan solusinya melalui diskusi forum. }\end{array}$ \\
\hline & & Streaming Expert. & $\begin{array}{l}\text { 11. Penyajian Materi pembelajaran oleh guru diikuti } \\
\text { dengan tanya jawab dan klarifikasi oleh guru. } \\
\text { 12. Video conference atau sekedar melihat video } \\
\text { streaming. Pada kegiatan ini dimungkinkan juga } \\
\text { terjadi diskusi antara peserta didik dengan ahli/pakar. } \\
\text { Jika web menggunakan sistem syncronus maka hal ini } \\
\text { sangat mungkin terjadi. }\end{array}$ \\
\hline
\end{tabular}


Kokom Komalasari, et al.

Mental Gymnastic

D Kegiatan Penutup Reflection

\subsection{Kegiatan Pelatihan} evaluasi.

Kegiatan Pelatihan dilaksanakan melalui tahapan persiapan, pelaksanaan, dan monitoring-

\subsubsection{Persiapan Program}

a) Langkah 1: Identifikasi dan Analisis Kebutuhan Pelatihan: Melakukan penjajagan kebutuhan guru terhadap peningkatan kompetensi pedagogic di dalam pembelajaran daring di saat pandemic COVID-19, serta mengetahui sejauh mana kebutuhan tersebut perlu dipenuhi melalui kegiatan "Pelatihan Desain Pembelajaran PKn Digita; berbasis Living values Education"

b) Langkah 2: Pembagian Tugas; Membagi tugas yang tepat terkait dalam pelatihan (panitia, fasilitator dan peserta/guru) untuk penyusunan standar-standar tertentu. Kegiatan dilaksanakan melalui analisis Uraian Tugas (Job Description), spesifikasi tugas, dan kualifikasi.

c) Langkah 3: Klasifikasi dan menentukan peserta pelatihan: Menentukan klasifikasi peserta disesuaikan dengan tujuan, sasaran pelatihan, ketersediaan sumberdaya pendukung pelatihan, yakni guru-guru PPKn SMP di Kabupaten Garut.

d) Langkah 4: Merumuskan Tujuan Pelatihan dengan memperhatikan ketercapaian tujuan aspek pengetahuan, sikap, dan keterampilan (Cognitive, Affective dan Psychomotor)

e) Langkah 5: Rancangan Program Pelatihan: Menentukan Isi/Muatan Materi Pelatihan (20\% teori dan $80 \%$ praktek) dan hubungan logis dan urutan materi, Menentukan Metoda \& Media Pelatihan yang menghendaki adanya keterlibatan aktif peserta pelatihan, dan menentukan kebutuhan waktu yang didasarkan pada "skala prioritas".

f) Langkah 6: Rencana Program Pelatihan: Menentukan siapa peserta pelatihan dan berapa jumlahnya, siapa fasilitator/pelatih, dimana tempat pelatihan akan dilaksanakan, waktu 
penyelenggaraan, kelengkapan pendukung, kebutuhan biaya dan menetapkan sumber dana, bahan pelatihan, teknis penyelenggaraan, dan dokumentasi.

g) Menyusun dan Mengembangkan Kerangka Acuan (TOR) yang berisi: Latar Belakang/Pendahuluan (Mengapa); Tujuan Pelatihan (Untuk Apa); Pokok Bahasan/Materi Pelatihan; Pendekatan dan Metodologi Pelatihan; Peserta Pelatihan dan Fasilitator; Waktu dan Tempat Pelatihan; dan Sumber dana dan Pembiayaan. Hal ini dilakukan untuk menunjang terlaksananya kegiatan pelatihan yang disusun sistematis sesuai acuan.

\subsubsection{Pelaksanaan Kegiatan Pelatihan}

Pelaksanaan pelatihan menggunakan desain waktu melalui model In-On Service Training sebagaimana dapat dilihat pada gambar berikut:

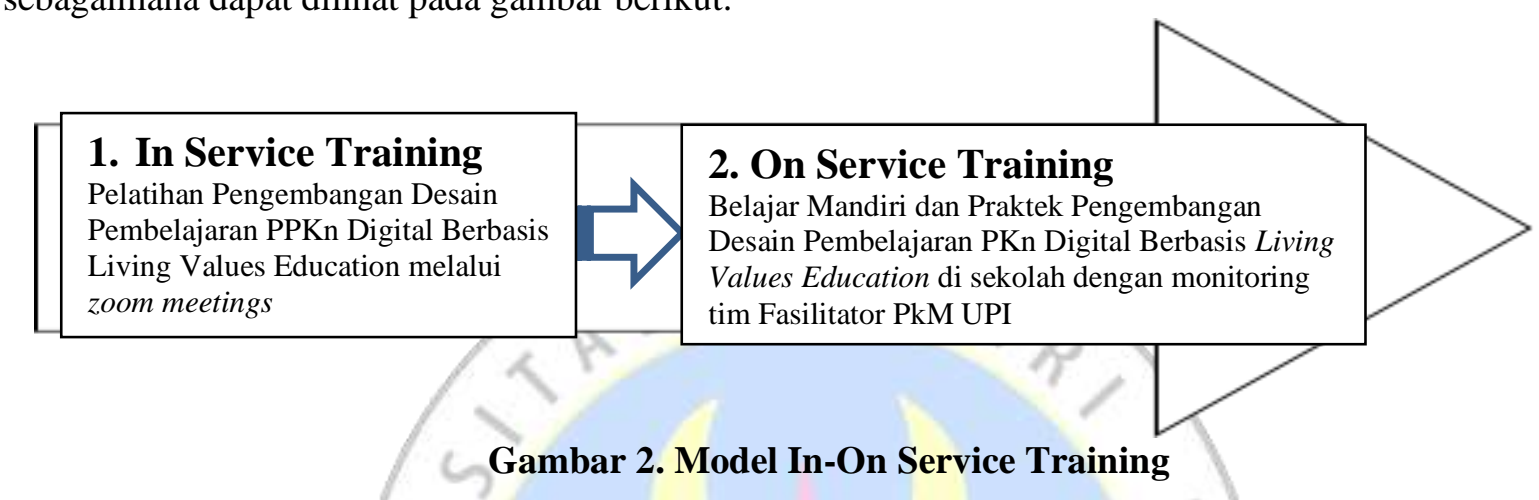

Model In-On Service Training terdiri atas kegiatan:

a) In-service Training, metode penyampaian materi pelatihan yang mengkombinasikan antara pemaparan teori tentang Desain Pembelajaran PKn Digital Berbasis Living Values Education dalam bentuk kegiatan presentasi, diskusi, simulasi, Latihan, dan diakhiri dengan penyusunan rencan tindak untuk kegiatan On Service Training. Kegiatan dilaksanaan di masa COVID-19, sehingga kegiatan In Service Training dilakukan dengan menggunakan media zoom meetings.

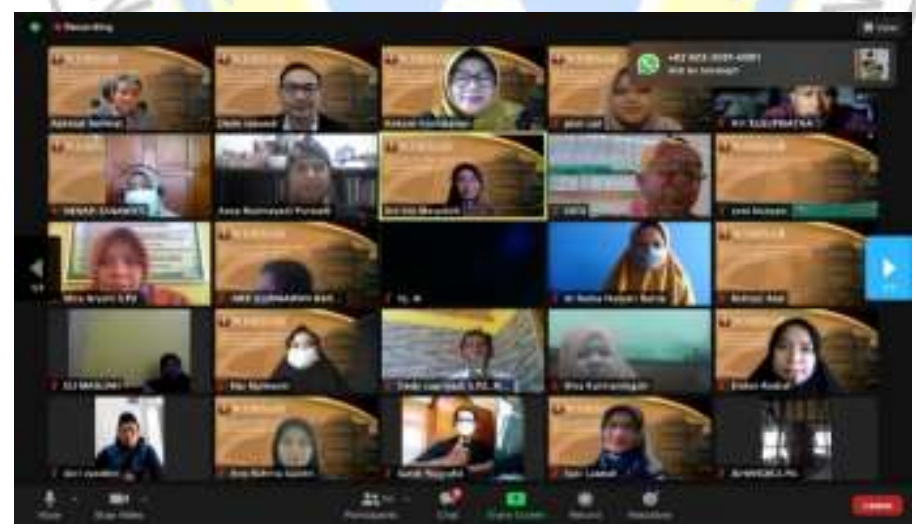

Gambar 3. Pelaksanaan in service training melalui media zoom meetings Sumber: Komalasari, et al., 2021

\section{b) On Service Training}

Kegiatan On service Training adalah tindak lanjut dari kegiatan in service training, yaitu praktek melaksanakan pengembangan Desain Pembelajaran PKn Digital Berbasis Living Values Education di kelas masing-masing sekolah dengan fasilitasi dan monitoring dari tim PkM UPI. Teknis yang digunakan adalah dengan cara mengelompokkan sekolah berdasarkan kedekatan lokasi, sehingga Tim 
PkM UPI lebih efektif dan efisien dalam melaksanakan pendampingan dan monitoring di lapangan langsung.

Adapun Agenda Acara in-on Service Training sebagaimana dapat dilihat pada tabel berikut.

Tabel 2. Agenda Acara in-on Service Training Agenda Acara in-on Service Training

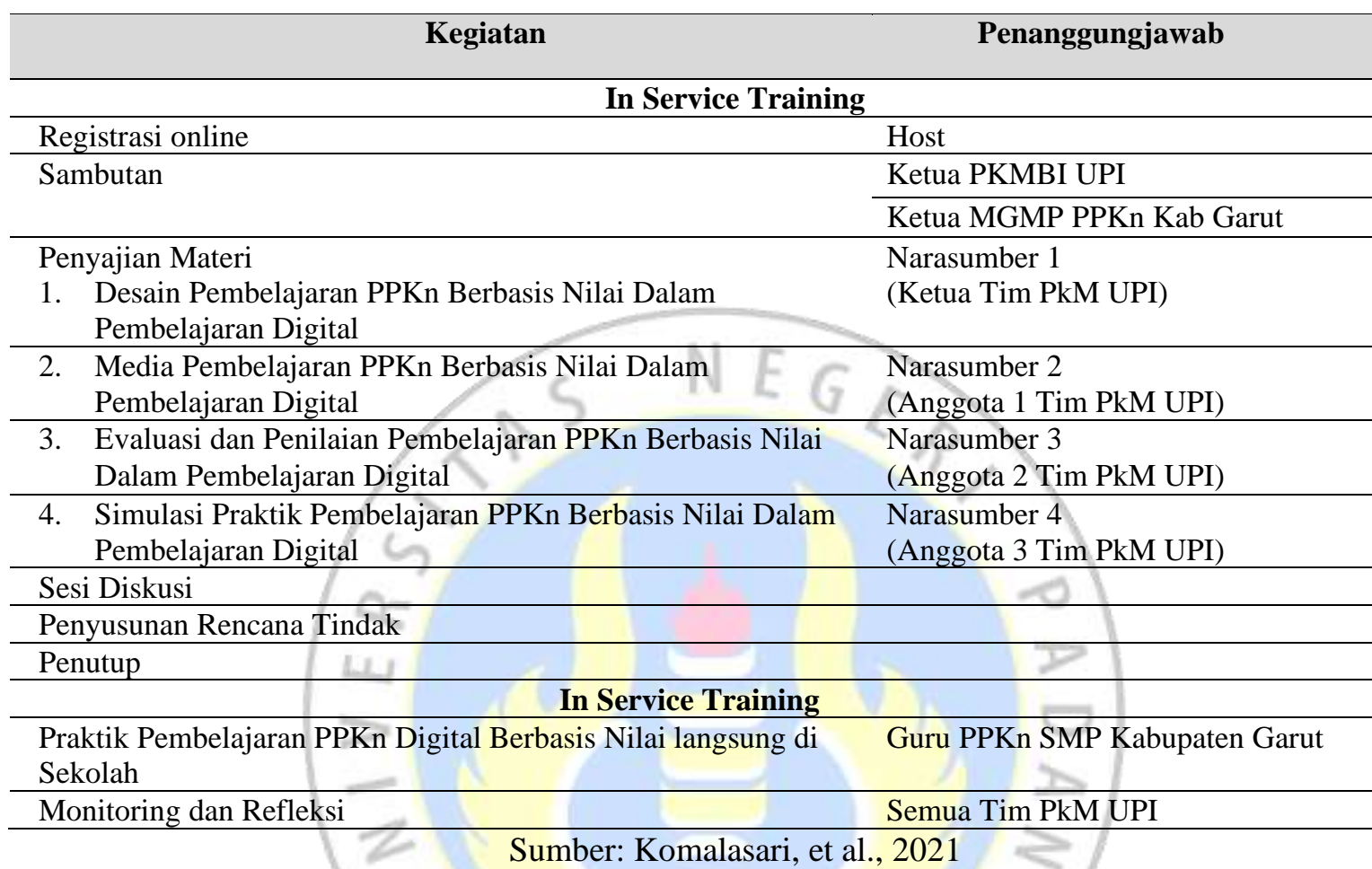

\subsubsection{Evaluasi Pelatihan}

Kegiatan ini dilakukan untuk kegiatan in-service training maupun on-service training. Evaluasi untuk kegiatan in-service training dilaksanakan menggunakan instrumen evaluasi penyelenggaraan diklat yang dilaksanakan diakhir pelatihan. Instrumen ini digunakan untuk mengukur tingkat relevansi dan efektifitas pelatihan berdasarkan kebutuhan peserta. Selain itu juga digunakan instrumen smiley face untuk mengukur tingkat kepuasaan peserta setiap hari diakhir pelatihan. Hasil evaluasi smiley face ini digunakan untuk bahan melakukan perbaikan pada hari berikutnya. Monitoring dan evaluasi kegiatan ini dilakukan oleh tim PkM berbasis Hasil Penelitian, MGMP PPKn SMP dan Dinas Pendidikan Kabupaten Garut. Hasil evaluasi terhadap persiapan dan proses hasil Penelitian diperoleh gambaran sebagai berikut, dengan ketentuan skor penilaian: 1 (kurang), 2 (cukup), 3 (baik), dan 4 (sangat baik).

Tabel 3. Penilaian terhadap Aspek Persiapan Pelatihan

\begin{tabular}{|c|c|c|c|c|c|}
\hline \multirow[t]{2}{*}{ No } & \multirow[t]{2}{*}{ Aspek Persiapan Pelatihan } & \multicolumn{4}{|c|}{$\begin{array}{c}\text { Skor Nilai } \\
(\mathbf{N}=\mathbf{8 1})\end{array}$} \\
\hline & & $1(\%)$ & $2(\%)$ & $3(\%)$ & $4(\%)$ \\
\hline 1 & $\begin{array}{l}\text { Penyebarluasan Informasi pelatihan kepada khalayak } \\
\text { sasaran }\end{array}$ & 0 & 1 & 10 & 88 \\
\hline 2 & Kemudahan melakukan pendaftaran pelatihan & 1 & 5 & 19 & 75 \\
\hline 3 & $\begin{array}{l}\text { Penyediaan sarana dan prasarana pendukung pelatihan (link } \\
\text { zoom, pemberian quota internet, sertifikat, powerpoint } \\
\text { materi) }\end{array}$ & 0 & 4 & 6 & 90 \\
\hline 4 & Kelengkapan Materi Pelatihan & 0 & 2 & 12 & 86 \\
\hline \multirow[t]{2}{*}{5} & Kesesuaian Materi pelatihan dengan kebutuhan & 0 & 4 & 14 & 81 \\
\hline & Nilai Rata-Rata & 0.2 & 3.2 & 12.2 & 84.4 \\
\hline
\end{tabular}


Sumber: Komalasari, et al., 2021

Berdasarkan data di atas, sebagian besar peserta menilai persiapan pelatihan sudah sangat baik (84.4\%), Sebagian kecil menganggap baik (14\%), dan cukup (3.2\%), bahkan tidak ada yang menilai kurang. Dengan demikian pelatihan desain pembelajaran PPKn digital berbasis living values education sudah dipersiapkan tim PKMBI UPI dengan sangat baik melalui Kerjasama dan koordinasi dengan Ketua MGMP PPKn SMP Kabupaten Garut. Komunikasi awal dilakukan dengan Ketua MGMP untuk menentukan waktu pelaksanaan dan khalayak sasaran, diikuti dengan penyebarluasan flyer (terlampir) dan link untuk registrasi peserta. Materi pelatihan sesuai dengan kebutuhan dan sarana prasaran pendukung (ketersediaan link zoom, sertifikat, dan powerpoint materi) disampaikan kepada khalayak, sehingga menarik minat peserta untuk mengikuti pelatihan. Hal yang masih menjadi kendala adalah registrasi online dan penggunaan zoom meeting seringkali terkendala sinyak kurang bagus dan keterbatasan quota internet. Kendala dapat diselesaikan dengan pemberian quota internet kepada peserta di akhir pelatihan. Peserta menghendaki pelatihan lanjutan secara luring, jika Pandemi COVID-19 sudah berakhir.

Tabel 4. Penilaian terhadap Aspek Proses Pelatihan

\begin{tabular}{|c|l|c|c|c|c|}
\hline No & \multicolumn{1}{|c|}{ Aspek Proses Pelatihan } & \multicolumn{4}{c|}{$\begin{array}{c}\text { Skor Nilai } \\
\text { (N= 81) }\end{array}$} \\
\cline { 3 - 6 } & & $1 \%(\%)$ & $2(\%)$ & $3(\%)$ & $4(\%)$ \\
\hline 1 & Pemahaman dan penguasaan materi instruktur & 0 & 0 & 8 & 92 \\
\hline 2 & Kejelasan dan Keruntutan dalam Menyampaikan materi & 0 & 4 & 13 & 83 \\
\hline 3 & Kemampuan instruktur memahami dan menjawab pertanyaan & 0 & 6 & 12 & 82 \\
\hline 4 & Sikap dan antusiasme instrukur & 0 & 0 & 28 & 72 \\
\hline 5 & Penguasaan instruktur terhadap media penyampaian materi & 0 & 0 & 10 & 90 \\
\hline 6 & Interaksi instruktur dengan peserta & 12 & 23 & 26 & 39 \\
\hline 7 & Pemanfaatam Waktu secara efektif & 0 & 0 & 16 & 84 \\
\hline & Nilai Rata-Rata & 1.7 & 4.7 & 16.1 & 77.5 \\
\hline
\end{tabular}

Sumber: Komalasari, et al., 2021

Data di atas menunjukkan bahwa peserta pelatihan sebagian besar (77.5\%) menilai proses pelatihan sudah sangat baik, hanya Sebagian kecil $(16,1 \%)$ menilai baik dan $4,7 \%$ menilai kurang, tetapi masih ada $1.7 \%$ yang menilai kurang. Dengan demikian pada aspek proses pelatihan, peserta Sebagian besar menilai instruktur sangat baik pada aspek pemahaman, kejelasan dan keruntutan, kemampuan menjawab pertanyaan, penguasaan media, sikap antusias, dan pemanfaatan waktu. Tetapi masih ada Sebagian kecil yang menilai kurang pada aspek interaksi instruktur dengan peserta. Hal ini sebenarnya dapat dimaklumi karena pelatihan dilaksanakan secara online menggunakan zoom meetings, sehingga interaksi tidak akan optimal jika dibandingkan pelaksanaan melalui luring (tatap muka langsung). Kendala tersebut diatasi dengan dibukanya komunikasi, konsultasi, dan pendampingan pasca pelatihan secara individual melalui whats app ataupun video conference secara mandiri.

\subsection{Hasil Pelatihan}

Peserta menghasilkan model pembelajaran PPKn daring berbasis living values, diantaranya sebagaimana contoh berikut ini. Pelatihan dianggap berhasil, jika dapat mencapai tujuan, yaitu meningkatnya pemahaman, kemampuan praktis dalam mendesain Pembelajaran PPKn Digital Berbasis Living Values dan menerapkannya dalam praktek pembelajaran sehari-hari di sekolah. Penilaian terhadap aspek hasil pelatihan dapat dilihat pada tabel berikut: 


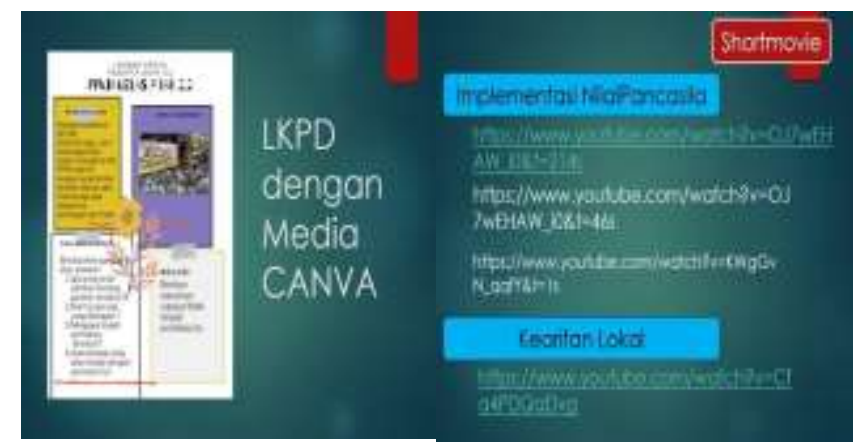

Gambar 4. Contoh Produk Model Pembelajaran Karya

Tabel 5. Hasil Pelatihan

\begin{tabular}{|c|c|c|c|c|}
\hline \multirow[t]{2}{*}{ No } & \multirow[t]{2}{*}{ Aspek Proses Pelatihan } & \multicolumn{3}{|c|}{$\begin{array}{l}\text { Skor Nilai } \\
(\mathrm{N}=81)\end{array}$} \\
\hline & & $1(\%)$ & $3(\%)$ & $4(\%)$ \\
\hline 1. & $\begin{array}{l}\text { Memahami cara mendesain pembelajaran PPKn Digital } \\
\text { berbasis living values }\end{array}$ & & 18 & 76 \\
\hline 2. & $\begin{array}{l}\text { Memahmi cara membuat media digital dalam } \\
\text { pembelajaran PPKn berbasis living values }\end{array}$ & 8 & 10 & 78 \\
\hline 3. & $\begin{array}{l}\text { Memahmi cara membuat instrument penilaian } \\
\text { pembelajaran PPKn digital berbasis living values }\end{array}$ & $2 \quad 8$ & 23 & 67 \\
\hline 4. & $\begin{array}{l}\text { Terampil membuat Desain pembelajaran PPKn Digital } \\
\text { berbasi living values secara komperensif }\end{array}$ & 9 & 22 & 66 \\
\hline 5. & $\begin{array}{l}\text { Terampil menerapkan Desain pembelajaran PPKn } \\
\text { digital berbasi living values }\end{array}$ & & 34 & 49 \\
\hline 6. & $\begin{array}{l}\text { Termotivasi untuk melanjutkan penerapan Desain } \\
\text { pembelajaran PPKn digital berbasis living values dalam } \\
\text { praktik pembelajaran PPKn sehari-hari }\end{array}$ & & 21 & 66 \\
\hline 7. & $\begin{array}{l}\text { Hasil pelatihan menunjang peningkatan kinerja } \\
\text { professional guru PPKn di era digital (online learning) }\end{array}$ & 3 & 12 & 85 \\
\hline & Nilai Rata-Rata & 7.8 & 20.3 & 69.7 \\
\hline
\end{tabular}

Sumber: Komalasari, et al., 2021

Data dalam tabel menunjukkan bahwa Sebagian besar $(69,7 \%)$ peserta menilai hasil pelatihan sangat baik, $20.3 \%$, baik (20.3\%), Sebagian kecil (7.8\%) cukup, dan hanya $2.2 \%$ yang menilai hasil pelatihan kurang. Dengan demikian sebagian besar pelatihan mampu meningatkan pemahaman peserta tentang cara mendesain pembelajaran, media, dan evaluasi berbasis living values education dalam pembelajaran PPKn Digital. Pada aspek praksis membuat desain Pembelajaran PPKn Digital Berbasis Living Values dan menerapkannya perlu pendampingan lebih intens dengan menggunakan model lesson study. Tetapi pada dasarnya peserta menilai pelatihan Pembelajaran PPKn Digital Berbasis Living Values sangat menunjang peningkatan kinerja guru PPKn professional dan memiliki motivasi tinggi untuk menerapkan Pembelajaran PPKn Digital Berbasis Living Values.

Pelatihan in-on service training ini dapat meningkatkan kemampuan teoritis dan praktis guru dalam pembelajaran PPKn Digital berbasis living values education. Hal ini dikarenakan: 1) Pelatihan dibutuhkan untuk melaksanakan tugas sebagai seorang guru professional di era digital (Robinson \& Robinson, 1989; Clark, 1991); 2) Pelatihan mengaktifkan peserta dalam penggalian pengalaman dan masalah keseharian guru dalam pembelajaran PPKn, sehingga berpendekatan experiential learning (Malcom Knowles dalam Lieb, 1991), dan pendekatan participant centered training) melalui kegiatan role-play, observasi, diskusi, brainstorming, simulasi pembelajaran, dan melakukan refleksi (Pike, 
2005; Fowlie : 2005; 3) model in-on service training lebih efektif (Mirici, 2006; Centre for Educational Research and Innovation, 1982), karena model ini dilengkapi dengan evaluasi pelatihan dan program tindak lanjut pelatihan, serta pendampingan, supervise, dan monitoring langsung di lapangan (Balchin, et.al., 2006).

\section{Kesimpulan}

Kegiatan Pelatihan sangat penting dalam upaya meningkatkan kompetensi professional dan pedagogic guru PPKn. Kegiatan Pelatihan didasari oleh hasil need assessment, sehingga pelatihan Desain Pembelajaran Digital Berbasis Living Values Education bagi Guru PPKn SMP Kabupaten Garut benar-benar bermanfaat. Bahan pelatihan berbentuk desain pembelajaran digital PKn yang menerapkan prinsip fun, flexible, and meaningful learning dengan langkah ice breaker dan opener, purposive cretaive thinking, peer to peer interaction, streaming expert, mental qymnastic, dan reflection dan mengintegrasikan prinsip living values education dalam keseluruhan langkah tersebut. Pelaksanaan kegiatan pelatihan meliputi tahapan persiapan, pelaksanaan model in-on service training (zoom meeting diikuti dengan pendampingan praktek pembelajarn di sekolah), monitoring dan evaluasi pelatihan; 3) Hasil pelatihan menunjukkan bahwa sebagian besar peserta memahami teori dan praksis cara mendesain pembelajaran PPKn digital berbasis living values education, tetapi pada aspek penerapan di kelas perlu pendampingan lebih intens dengan menggunakan model lesson study.

\section{Daftar Pustaka}

Achmat, Z. (2005). Efektifitas Pelatihan Pengembangan Kepribadian dan Kepemimpinan dalam Meningkatkan Kepercayaan Diri Mahasiswa Baru UMM Tahun 2005/2006. Laporan Penelitian. Malang: Lembaga Penelitian Universitas Muhammadiyah Malang (tidak diterbitkan).

Anderson, T. (2008). The Theory and Practice of Online Learning. Second Edition. AU Press Canada. Athabasca University.

Balchin, N., Randall, L., \& Tunner, S. (2006). The couch consult methods: A model for a sustainable change in schools. Educational psychology in practice. 22(3), 237-254.

Bonk, C. J., \& Dennen, V. (2003). Frameworks For Research, Design, Benchmarks, Training, And Pedagogy In Web-Based Distance Education. In M. G. Moore \& W.G. Anderson (Eds.), Handbook of Distance Education (pp. 331-348). Mahwah, NJ: Lawrence Erlbaum Associates.

CERI (Centre for Educational Research and Innovation). (1982). In-service education and training of teachers: A condition for educational change. Paris: OECD.

Clark, N. (1991) Managing Personal Learning and Change, A Trainer's Guide. London : McGraw-Hill Book Company.

Direktorat Jenderal Guru dan Tenaga Kependidikan Kemendikbud RI. (2019). Data Verifikasi Pusat Data dan Statistik Pendidikan dan Kebudayaan, Juli 2019.

Fowlie, J. (2000) Emotional Intelligence: The Role of Self-Confidence in Preparing Business School Undergraduates for Placement/Employment. http://www.herts.ac.uk

Greenway, R. (2005) Experiential Learning Cycles. $\underline{\text { http://reviewing.co.uk/research/ }}$ learning.cycles.htm

Kementerian Pendidikan dan Kebudayaan. (2020). Surat Edaran Menteri Pendidikan dan Kebudayaan Nomor 4 Tahun 2020 Tentang Pelaksanaan Kebijakan Pendidikan dalam Masa Darurat Penyebaran Coronavirus Disease (Covid-19).

Komalasari, K. (2010). Pembelajaran Kontekstual: Konsep dan Aplikasi. Bandung: Refika Aditama.

Komalasari, K \& Saripudin, D. (2017). Pendidikan Karakter: Konsep dan Aplikasi Living Values Education. Bandung: Refika Aditama.

Komalasari, K, \& Saripudin, D. (2017a). Value-Based Interactive Multimedia Development through Integrated Practice for The Formation of Students' Character, Turkish Online Journal of Educational Technology, 16(4). 179-186. https://files.eric.ed.gov/fulltext/EJ1160605.pdf 
Kokom Komalasari, et al. Pelatihan Desain Pembelajaran Digital Berbasis Living Values Education bagi Guru PPKn SMP di Kabupaten Garut

Komalasari, K., \& Rahmat (2019). Living Values Based Interactive Multimedia in Civic Education Learning. International Journal of Instruction, 12(1), 113-126. https://doi.org/10.29333/iji.2019.1218a

Komalasari, K., Rahmat., Masyitoh, IS., Iswandi, D. (2021). Pelatihan Desain Pembelajaran Digital Berbasis Living Values Education bagi Guru PPKn SMP di Kabupaten Garut. Laporan Pengabdian kepada Masyarakat Bidang Ilmu. Bandung. Tidak diterbitkan.

Komalasari, K., Firiasari, S., Anggraini, D.N., (2021a). Living Values-Based Digital Learning Resources in Civic Education, The New Educational Review, 83(1), 85-98.

Lieb, S. (1991) Principles of Adult Learning. http://honolulu.hawaii.edu/intranet/ committees/ FacDevCom/guidebk/teachtip/adults-2.htm.

Mirici, I.H. (2006). Electronic in-service teacher-training for the new national EFL curriculum in Turkey. Turkish online journal of distance education-TOJDE. 7(1), 155-164.

Munir. (2017). Pembelajaran Digital. Bandung: CV. Alfabeta

Pike, B. (2005) The More Effective Alternative to Lecture-Based Training. http://www.bobpikegroup.com/seminars/whatis_pct.html

Robinson, D.G. dan Robinson, J. C. (1989) Training for Impact: How to Link Training to Business Needs and Measure The Results. California: Jossey-Bass Inc., Publishers.

Tillman, D. (2004). Living Values: Avtivities for Children Ages 8-14. Jakarta: PT Gramedia Widiasarana Indonesia. 